\title{
TRENDS AND BRAZILITY AT FEMALE BEACH FASHION COLLECTION
}

\author{
Lorena da Silva Leite \\ Celso Suckow da Fonseca Federal Center for \\ Technological Education \\ Río de Janeiro, RJ, Brasil \\ lorena silvaleite@hotmail.com
}

\author{
José André Villas Boas Mello \\ Celso Suckow da Fonseca Federal Center for \\ Technological Education \\ Río de Janeiro, RJ, Brasil \\ joseavbm@yahoo.com.br
}

Reception Date: 09/03/2019 - Approval Date: 19/06/2019

\section{ABSTRACT}

The objective of this article is to identify the Brazilian marketing attributes presented in the fashion trends of the 2017 collection presented at the two brazilian events, São Paulo Fashion Week (SPFW) and Rio Moda Rio (RMR). This work can be considered an exploratory and descriptive article, especially when it comes to detect trends and changes in behavior. It is possible to conclude that, in part, the attributes of brasility are present in the beach fashion segment. The beach fashion presented in the collection does not contain all the elements of Brazilianness due to market trends. The cultural metaphors are absorbed by the fashion industry, which adapts its products to contemporary women, adapting its portfolio according to the profile of women who are consumers of the moment. It is possible to conclude that the Brazilian attributes are part of the beach fashion segment, however, for the trends of 2017, conclude that the 4 requirements, cited by Sutter (2014), lifestyle, application of craft techniques, shape and volumen, and print attribute, are included at actual trends. Among the attributes of Brazilian studies only the tissue was not found in any of the events studied, the use of ecological and sustainable tissues, apparently, were not used in the collections. This study becomes relevant and original in the way it is conducted, since it recognizes that the trends presented in the fashion collections represent the marketing work and show that several characteristics that are also Brazilian attributes.

KEY WORDS: Beach fashion; Collection; Brazility.

\section{INTRODUCTION}

Culture not only treats reality through conventions, but also invents it from the conventional symbolism (Ribeiro, 2013). Such cultural aspects are the result of the consideration and incorporation by the industry of individual and collective behaviors, especially those of consumption. Rahman and Gong (2016) point out that many consumers "Visión de Futuro" Año 16, Volumen N²3 N², Julio - Diciembre 2019 - Pág. 157 - 171 URL de la Revista: http://visiondefuturo.fce.unam.edu.ar/index.php/visiondefuturo/index URL del Documento: http://visiondefuturo.fce.unam.edu.ar/index.php/visiondefuturo/issue/view/ ISSN 1668 - 8708 - Versión en Línea 
like what is called fad, plentiful and affordable options attract attention. However, other consumers and environmental advocates have begun to question the volatility of this system, including problems of over-consumption and disposable products. Schuch (2016) points out that population growth, increased demand for textiles, water and arable land will influence how fashion is produced and consumed. According to Pereira et al. (2011), if we compare the transformations that have occurred in the fashion industry with any other industries, in a given period, we can see that it is a market with extremely volatile demands.

The search for these needs intensifies the competitiveness between organizations, Martins and Laugeni (2005) argue that the competitive capacity of an organization is determined by the recognition of the needs of the consumers and how to achieve them. Frings (2012) adds this theory, saying that the consumer is a major contributor to these changes, as their needs and desires create a cycle of consumer demand that the industry aims to meet. According to Woitowicz (2006) recognize the culture image figure as part of the daily, because it establishes a closer look around the ideals consumption.

According to these affirmations, it is possible to assume that the transformations in the market for Women's Beachwear (MWB) are influenced by metaphors recognized by women, which consequently cause companies to seek mechanisms to meet their needs and this attempt increases competitiveness among the companies in this segment. One way to meet these expectations and to stand out from competitors is to appropriately predict trends, which are defined in the first stage of the production process. Chan et al. (2017) emphasize that responsiveness to customers and markets is an indispensable requirement for all industries, particularly fashion.

Some researchers have sought evidence on management and efficiency of the processes and products developed by the fashion industry. Among them, can be mentioned Lueg et al. (2015), Ma e Hu (2017), Macchion et al. (2015), Chan et al.(2017), Sutter et al.(2014). Understanding the trends aspects that can be explored by the textile and retail industries requires recognizing the national standards that gain new versions for each fashion collection launch, a marketing role that aims to propose a new idea directed to a potential consumer group. In view of these aspects, the objective of this article is to identify the Brazilian attributes present in the trends of beach fashion in 2017 collections presented at the two main brazilian events, São Paulo Fashion Week and Rio Moda Rio.

Know the strategies of the consumer market for beachwear constitutes a relevant issue for marketing women studies, since the purchasing power and the demand of the consuming woman in each consumption cycle are increasingly object of attention by the designers of trend. Sutter et al. (2016) emphasize that the understanding of the differentiating elements that make up the brasilian fashion offer deepens the knowledge about the competitiveness of each 
collection launched. Assis (2010) reinforces this importance by mentioning that women have a fundamental participation in society, due to the significant increase in their social, political and economic activities. Khraim (2018) says that fashion industry growth can be attributed to fact that people are up to date with the latest trends and fashions has become a part of the lifestyle of most individuals.

In addition to this introduction, this paper presents a section that discusses the theoretical foundations on fashion and Brazilianity that are included in this work. Following are the materials and methods section and the search results in the sequence, and finally, the conclusions and the references.

\section{DEVELOPMENT}

\section{Attributes and characteristics in fashion}

Fashion industry is a global industry which makes and sells clothes (Tovmasyan, 2017). The fever of fashion weeks and its repercussion in the press began in the 1990s and revealed the movement of the textile and clothing industry and the production of young and renowned designers; together with the success of Brazilian models. The consolidation of such summer or winter launch events, at the same time as, on the one hand, has potentiated the fashion business sector in economic terms; on the other, it has provided the growth of journalistic coverage. They became media events and mediaized, which only exist if they are publicized and publicized (Hinerasky, 2007).

Events like these are a way of attracting interested in fashion and take them to fashion shows and have the opportunity to see classic and new brands up close, following the new trends that are going to occupy the clothing stores throughout the country. In each fashion show, new tendencies related not only to clothing models, but also to the types of fabrics used during the next season, new and / or old (when they come back) cuts and models, jewelery and accessories, hair, shoes, etc. makeup, among others. Every year there are great fashion shows around the world, known as fashion weeks (Borges, 2017). The major events of international fashion usually occur twice a year, being one during the first semester (until March), where the brands parade their fall-winter collections, and another in the second semester (between the months of October and November), where spring-summer collections are launched. Among the most famous fashion weeks are the fashion weeks of New York, Milan, Paris, London, and Sao Paulo Fashion Week.

Brazilian fashion events are among the five largest in the world (ABIT, 2016). These events consist of parades for the presentation and commercialization of collections, each

\footnotetext{
"Visión de Futuro" Año 16, Volumen N²3 N², Julio - Diciembre 2019 - Pág. 157 - 171

URL de la Revista: http://visiondefuturo.fce.unam.edu.ar/index.php/visiondefuturo/index

URL del Documento: http://visiondefuturo.fce.unam.edu.ar/index.php/visiondefuturo/issue/view/16

ISSN 1668 - 8708 - Versión en Línea

E-mail: revistacientifica@fce.unam.edu.ar
} 
season has a different calendar and they happen as follows: summer collections are released between the months of April to May, those of winter between October and November, basically. One can mention São Paulo Fashion Week, Minas Trend and Rio Moda Rio as the main events of the segment in the country.

Market competitiveness leads companies to use new alternatives to improve customer service mechanisms (Monteiro et al, 2017), and technologies in order to achieve some advantage over their competitors (Pimenta, 2019). Porter (1989) argues that this competitive advantage can be achieved in two ways, by the presentation of differentiated costs, or by authentic characteristics of the product.

In the fashion segment it is no different, to present itself competitively, one of the aspects that influence this task is to have an assertive image within the international market. Still in this direction, Carmona and Quintero (2008) cite that changes in fashion globally have led to accelerated innovations, both technological and organizational. Strey (2000) mentions that fashion is, among other things, a continuous dialogue between the natural and the artificial. Sometimes it adjusts to the format of the body and sometimes tries to modify that format through numerous devices.

Sutter et al. (2014) argue that it is possible to achieve a certain advantage even with similar products, provided they have unique characteristics that are obvious to consumers. According to Ayrosa (2000), the image that a country transmits is considered a relevant variable in the strategic mapping of organizations, since it affects directly in the purchasing decision process. Therefore, Hakala et al. (2013) ensure that if the country has a positive image, it can build a favorable reputation for a whole category of products.

About the country image origin, Kotler and Gertner (2002) affirm that it is equivalent to the result of the processing and the people's choice, beliefs and impressions about certain place. Similarly, Wang et al. (2012), portray that the image of the country origin is the cognitive reflex of consumers about the economy, technology, politics and society of a country. By virtue of the above, one can define the image of the country of origin as the understanding that the consumers have in relation to the interaction of the cultural, technological, political, economic and social manifestations of this country.

Fashion companies need to supply consumers with a convenient access to relevant fashion-related information to update them on new fashion trends on regular basis (Khraim, 2018). Sutter et al. (2014) cite the existence of their own characteristics, attributes of Brazilianness, a set of elements that constitute a representation of Brazil's culture and individuality, that is, historical and cultural associations that make up an image that is authentically considered as national. Sutter carried out an exploratory, qualitative and exploratory research in 2014. In the study identified the attributes of Brazilian implicit in the 
production of our image before the international market. In this survey, we found 8 (eight) main attributes, which are represented by the following items:

- Forms and volumes;

- Lace, applications and craft techniques;

- Representations of Brazil, with cultural and national symbols;

- Cheetah fabrics, linen, lightweight, fiber tracing;

- Lifestyle, Daring; diversity of cultural traditions; a nation's lifestyle incorporated into products;

- cheerful motifs and colors, tropical chromatic tones; primary and secondary colors, coordination and color composition.

- Natural Raw Materials;

- Print with large colorful flowers, tropical foliage and showy fruits.

As for the image transmitted by Brazilian fashion in the international market, it is correct to say that it is not yet determined. For Braga (2008), this lack of definition is due to the recent construction of the fashion identity in the country that began only in the late 1980s, yet Brazil (even with its diversity in its tendencies) can make use of the Brazilian prestige in this market segment.

The term trend comes from the Latin tendentia, which means to tend to, lean toward, or be attracted to. This subjective characteristic can be perceived and understood through research, where the future habits of consumers are projected (Bergamo, 1998). Rech and Campos (2015) reinforce this idea, stating that trends are the mirror of the posthumous, that is, reflect the future projections of the way of life of individuals. Engel (2000) adds that trends can be determined by identifying influences in a given segment and how they will behave in the future. According to these authors, it is possible to summarize the description of what is tendency as the conscious or non-conscious reflection of the consumer in a near horizon.

The assimilation of trends is the basis of all work for companies in the fashion industry, shows the specifications that the collections are made. However, it is not an easy task to predict such trends as they are dynamic and change according to what is happening in the world at the moment. From this, Silva et al. (2011) reinforce that the first step in the development of a new collection is the exploration of the various sources of fashion trends. For this, Frings (2012) points out that it is necessary to observe and follow certain market icons, such as: politics, economics, music, demography and social changes; the inspirations of great brands and parades; fashion magazines; the newspapers; trend and design reports; fashion sites or video and television services in order to recognize the implicit aspects.

Dressing precedes verbal communication by establishing an individual gender identity,

\footnotetext{
"Visión de Futuro" Año 16, Volumen N²3 N², Julio - Diciembre 2019 - Pág. 157 - 171

URL de la Revista: http://visiondefuturo.fce.unam.edu.ar/index.php/visiondefuturo/index

URL del Documento: http://visiondefuturo.fce.unam.edu.ar/index.php/visiondefuturo/issue/view/16

ISSN 1668 - 8708 - Versión en Línea

E-mail: revistacientifica@fce.unam.edu.ar
} 
as well as expectations for other types of behavior (social roles based on that identity) (Strey, 2000). Analyzing the behavior of these channels over a period is likely to detect the product characteristics that will please customers. Some style ideas can be found simultaneously in different collections of different brands, because many designers can make use of the same sources of inspiration.

\section{Materials and methods}

This work can be considered as exploratory and descriptive, especially when it comes to detecting trends and changes in behavior. Descriptive research can also approach exploratory research, when its objectives seek a new view on a case (Gil, 2002). One of the forms of data collection was performed through a survey in the fashion sector, where the trends will be evident in women's swimsuits for the 2017 collections were known.

The bibliographic analysis was also a resource used to obtain qualitative data, it was necessary to carry out a chronological survey of the sector and how its evolution took place over time. This retrospective allowed us to understand how this dynamic market works, how it can keep up with the constant changes and predict the trends of the next collections. According to Delgado (2008), the fashion market experiences constant changes, always seeking new inspirations and trends, which make one collection different from the other. As a result, this research evaluates the collections of the 2016/17 Summer Beachwear for Women, following the national fashion launching calendar between April and May 2016.

For the evaluation parameters, this work wil have as global inspiration Sutter (2014) that presented characteristics, table 1, that are authentically considered as Brazilian, Sutter carried out in 2014 an empirical research, of exploratory nature and with qualitative approach.

Table $\mathrm{N}^{\circ}$ 1. Brazilian fashion attributes

\begin{tabular}{|c|l|}
\hline Attribute & \multicolumn{1}{c|}{ Elements } \\
\hline Lifestyle & $\begin{array}{l}\text { Slogan to like life; daring; diversity of cultural traditions; the lifestyle of a mixed-race } \\
\text { nation that is incorporated into products; irony and joy of living. }\end{array}$ \\
\hline $\begin{array}{c}\text { Representations } \\
\text { of Brazil and } \\
\text { national symbols } \\
\text { Use of images of flora and fauna (in prints), with foliated prints, fruits, coconut trees, } \\
\text { flowers, jaguars, parrots, toucans or pieces embroidered with macaws in sparkles } \\
\text { and sequins. Tropical ecology; typography, engraving, carving, pottery, cooking, } \\
\text { religious and folkloric practices; cultural manifestations; Reconciliation of the } \\
\text { references of the national culture with the modernity in the elements that make } \\
\text { reference to the geographic of the country, as: nature, use of colors green and yellow; } \\
\text { elements that establish a direct relationship with Brazil, such as: beaches, coconut } \\
\text { trees, favelas, samba, indigenous and African culture, religiosity and images of } \\
\text { Carmen Miranda. }\end{array}$ \\
\hline Colors & $\begin{array}{l}\text { Cheerful motifs and colors, primary and secondary colors, tropical chromatic hues; } \\
\text { coordination and composition of colors. }\end{array}$ \\
\hline
\end{tabular}

Visión de Futuro" Año 16, Volumen Nº 23 N², Julio - Diciembre 2019 - Pág. 157 - 171

URL de la Revista: http://visiondefuturo.fce.unam.edu.ar/index.php/visiondefuturo/index

URL del Documento: http://visiondefuturo.fce.unam.edu.ar/index.php/visiondefuturo/issue/view/16

ISSN 1668 - 8708 - Versión en Línea 


\begin{tabular}{|c|c|}
\hline $\begin{array}{ll}\text { Natural } & \text { Raw } \\
\text { Materials } & \end{array}$ & $\begin{array}{l}\text { Fibers, gems, metals; seed, feathers, scales, shells; stones, wood beads, straw yarn; } \\
\text { handicrafts produced from buriti fibers. }\end{array}$ \\
\hline $\begin{array}{l}\text { Craft } \\
\text { Applications and } \\
\text { Techniques }\end{array}$ & $\begin{array}{l}\text { Lace; embroidery, manual finishing - tied, shredded, red; Texture (worked wool, rustic } \\
\text { acrylic), fillet, bobbin lace, labyrinth; spinning, lace, basketwork; traditional techniques } \\
\text { and use of lace, knitting, crochet, application of attachments, buttons, Ribbons of the } \\
\text { Lord of Bonfim among others; bijouterie with seeds of plants, technique of the } \\
\text { indigenous and macramés (indigenous artisanal technique executed through us) of } \\
\text { vegetal materials; the fuxicos, patchwork, patchwork, little ones. }\end{array}$ \\
\hline Fabrics & $\begin{array}{l}\text { Cheetah; linen, light fabrics, textile fiber (Indian); basketry, ecological, natural cotton, } \\
\text { buriti fiber, cambraia, jute. }\end{array}$ \\
\hline Print & $\begin{array}{l}\text { Colorful big flowers, tropical foliage and showy fruits; simplified features that rescued } \\
\text { the tropical nature; Press Shop; live prints, illustrations of Alceu Penna as: the } \\
\text { trickster, the boardwalk of Copacabana, the Chintz and Bahia. }\end{array}$ \\
\hline $\begin{array}{l}\text { Shapes and } \\
\text { volumes }\end{array}$ & $\begin{array}{l}\text { The development and preparation of each piece, which can be: revealing low-cut, } \\
\text { short, fluttering or even half-open, reminding, in part, the native nudity; cuts, } \\
\text { simplicity, creativity between art and matter, relaxed pieces with light shapes and } \\
\text { textures. }\end{array}$ \\
\hline
\end{tabular}

Source: Sutter et al. (2014)

The collection of women's summer beachwear 2016/2017 will be called in every work of fashion women's beach summer 2017 (MWB 2017), in addition to facilitate in the description most of the summer is arranged in the year 2017, since, the official date of the summer is from $12 / 21 / 2016$ to $03 / 21 / 2017$.

\section{Brazilianity and trends in MWB 2017}

On the trends established for MWB 2017, common characteristics were observed among the various collections, which were determined by the market as the main trends, namely: handicrafts, hang gliding, floral pattern, earthy tones, beach exit in the kimono model and long dress (Carasco, Mahawasala, Guide of the Week, Garcez, 2016). After knowing these tendencies, an inquiry was made to the collection of the parades presented at SPFW and RMR, which are the main fashion events in Brazil. In order to substantiate clearly what the vehicles showed, the aspects were as follows:

The first relevant attribute identified is Craft Techniques with fringes, (figure 1) - the very diversified in the making of handicrafts, which can also be noticed in the beach pieces. Especially noteworthy are handmade applications such as crochet, embroidery, fringes, ropes and rings. These devices value manual work and give a more personalized feel to the 
workpiece.
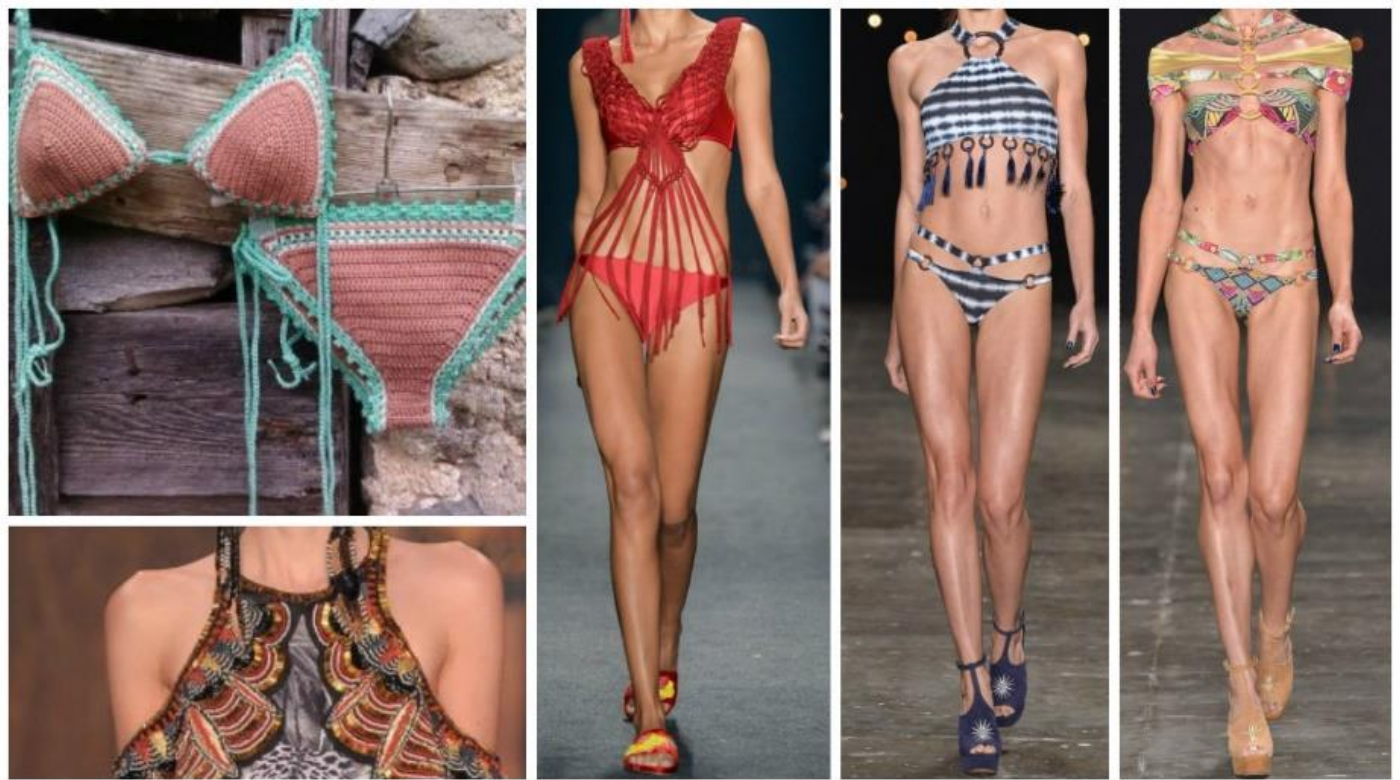

Figure № 1 . Handicrafts (crochets, embroidery, fringes and rings)

Source: Adapted from FFW (2016) and RMR (2016)

Hang Glider Bikini (Figure 2) - a trend that was successful in the late 1980s and early 1990s, characterized by a highly revealing cut, with a more pronounced pit in the groin area, leaving the legs more exposed.
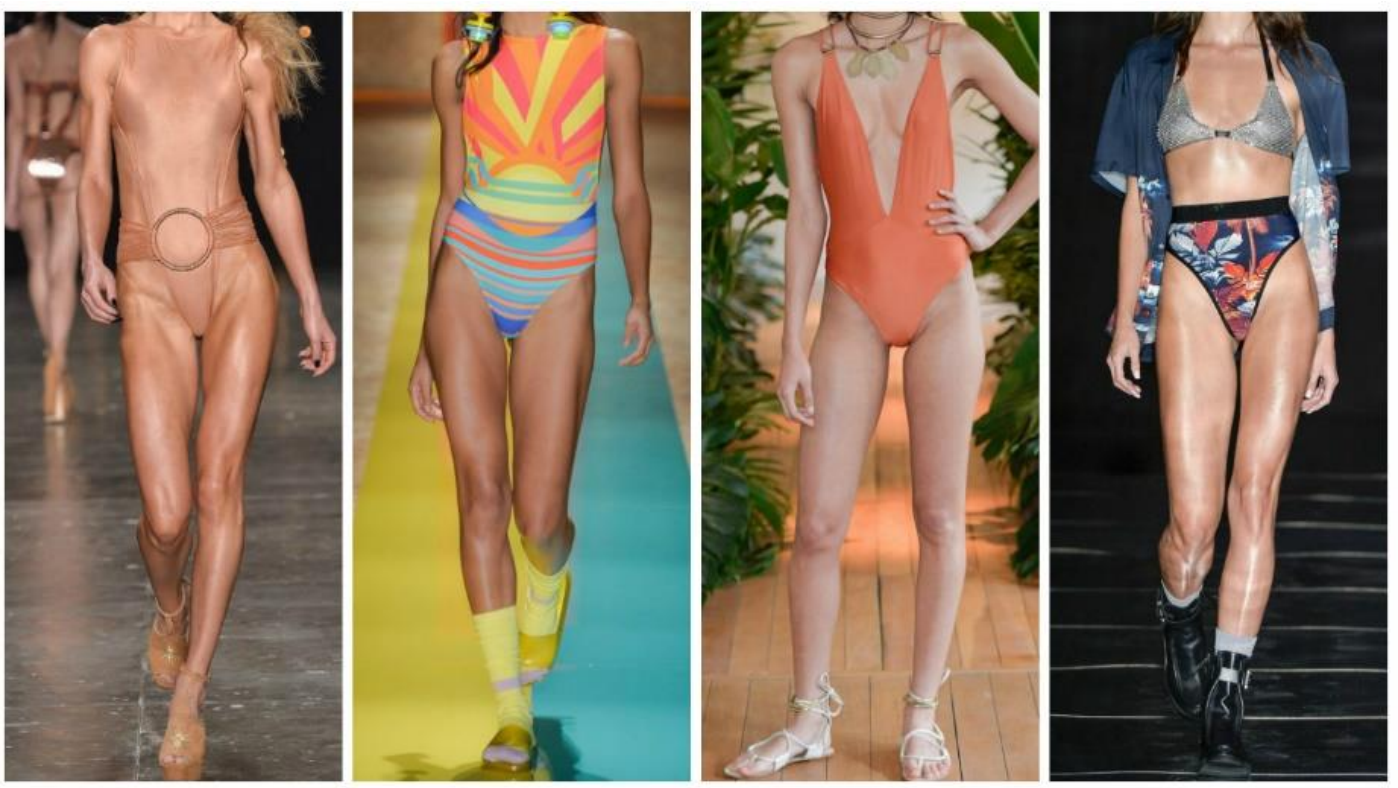

Figure № 2. Hang glider bikini

Source: Adapted from FFW (2016) and RMR (2016)

Visión de Futuro" Año 16, Volumen No 23 No2, Julio - Diciembre 2019 - Pág. 157 - 171

URL de la Revista: http://visiondefuturo.fce.unam.edu.ar/index.php/visiondefuturo/index

URL del Documento: http://visiondefuturo.fce.unam.edu.ar/index.php/visiondefuturo/issue/view/16

ISSN 1668 - 8708 - Versión en Línea

E-mail: revistacientifica@fce.unam.edu.ar 
Floral Pattern (figure 3) - show the flowers and their exuberance, making a contrast between different types of flowers and their color variations.
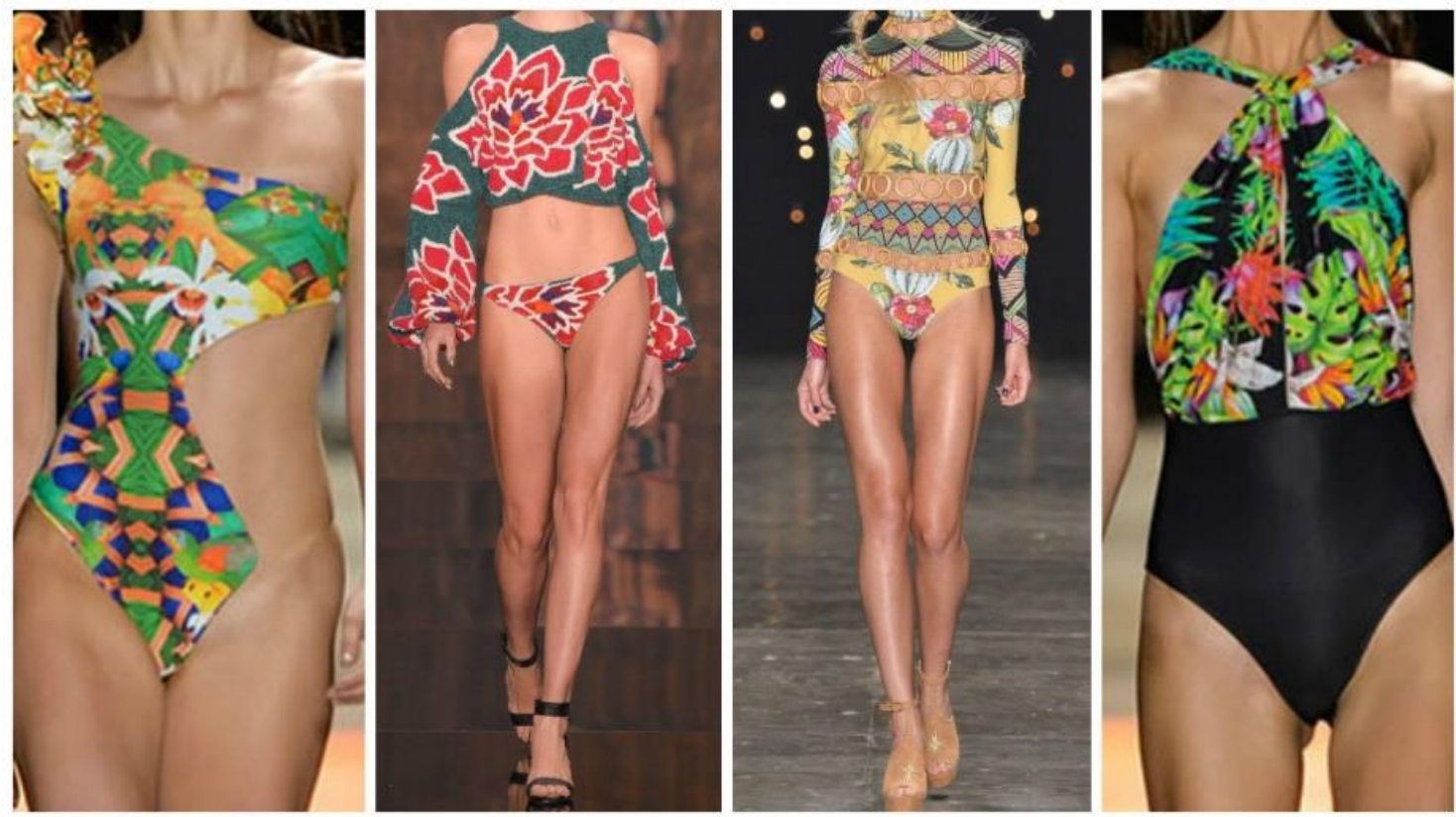

Figure № 3. Floral pattern

Source: Adapted from FFW (2016) and RMR (2016)

KIMONO (Figure 4) - After successful streetstyle kimonos invaded the beaches, this eastern influence became a trend mainly on the beach exits.
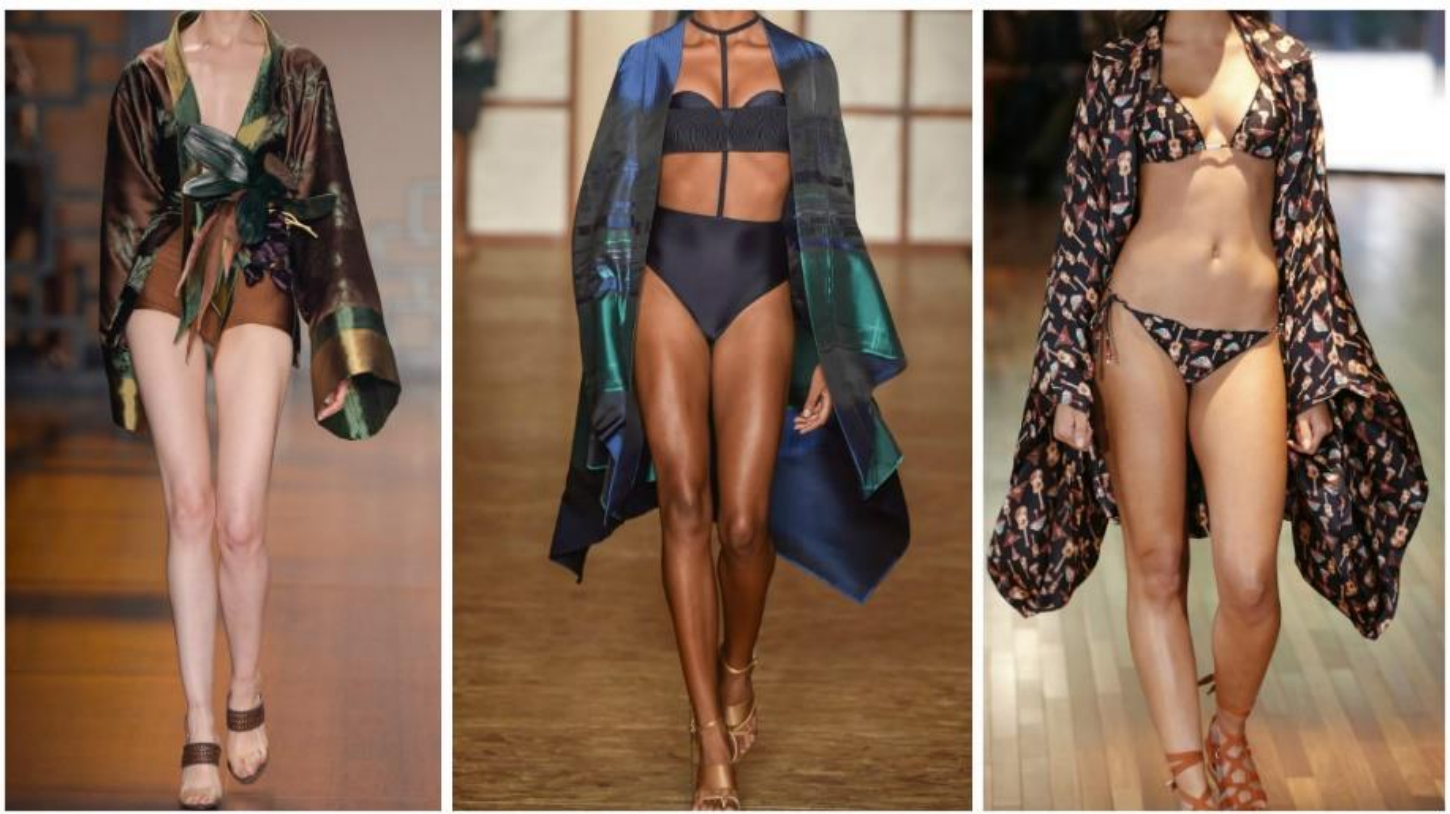

Figure № 4. Beach exit - kimono

Source: Adapted from FFW (2016) and RMR (2016)

\footnotetext{
"Visión de Futuro" Año 16, Volumen No 23 No2, Julio - Diciembre 2019 - Pág. 157 - 171

URL de la Revista: http://visiondefuturo.fce.unam.edu.ar/index.php/visiondefuturo/index

URL del Documento: http://visiondefuturo.fce.unam.edu.ar/index.php/visiondefuturo/issue/view/16

ISSN 1668 - 8708 - Versión en Línea

E-mail: revistacientifica@fce.unam.edu.ar
} 
Long Dress (Figure 5) - these longer beach outfits are made with lighter and more sophisticated fabrics, which bring more elegance and style to the segment, the purpose is to be ready for any occasion when leaving the beach.
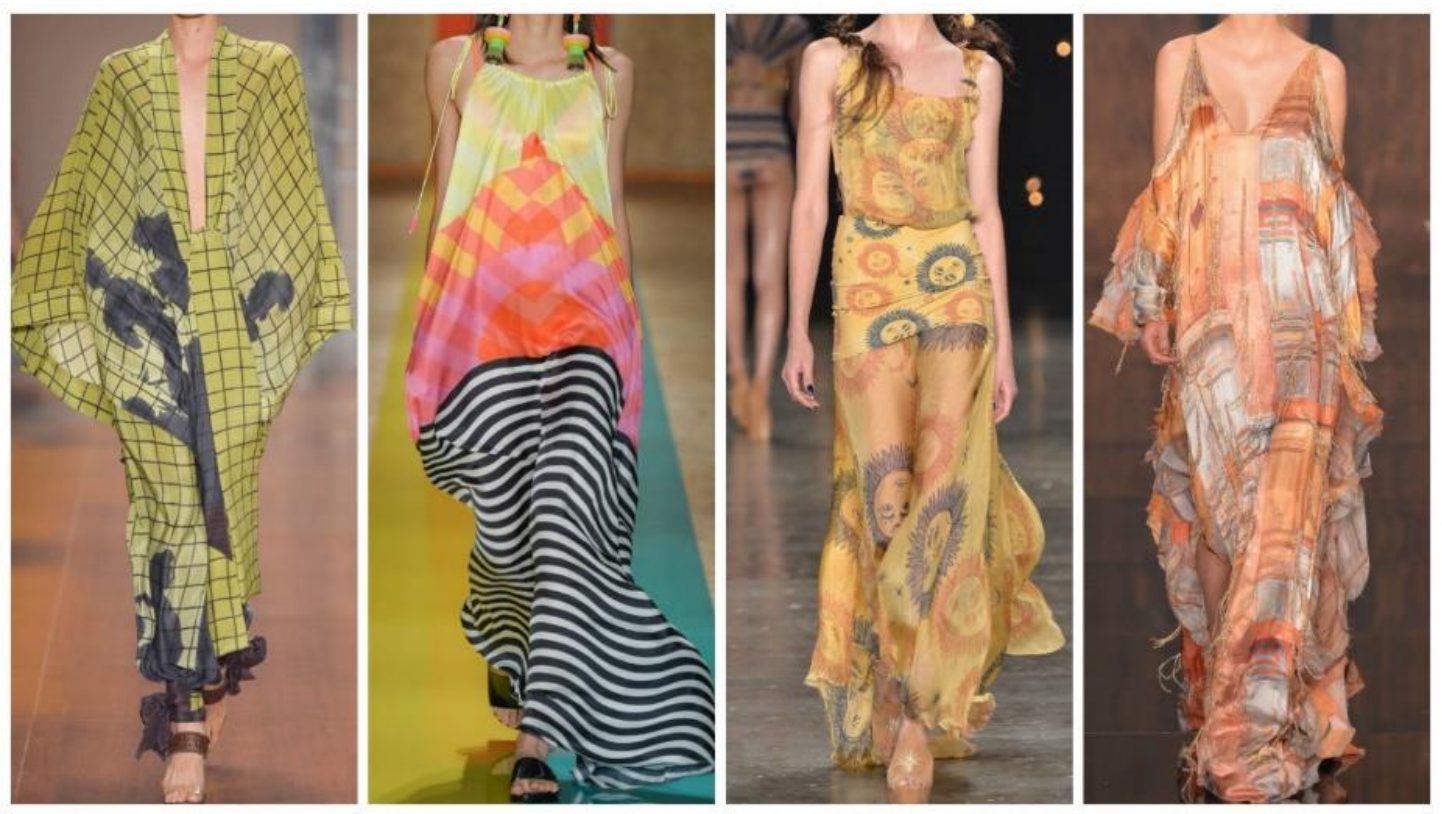

Figure № 5. Beach exit - long dress

Source: Adapted from FFW (2016) and RMR (2016)

Earthy tones (figure 6) - although the country is known for the presentation of primary and secondary colors, the trends of this summer show the earthy tones and their derivations of nuances, such as brown, golden and nude. The goal of stylists is to highlight the beauty of tanned skin and the sun. 

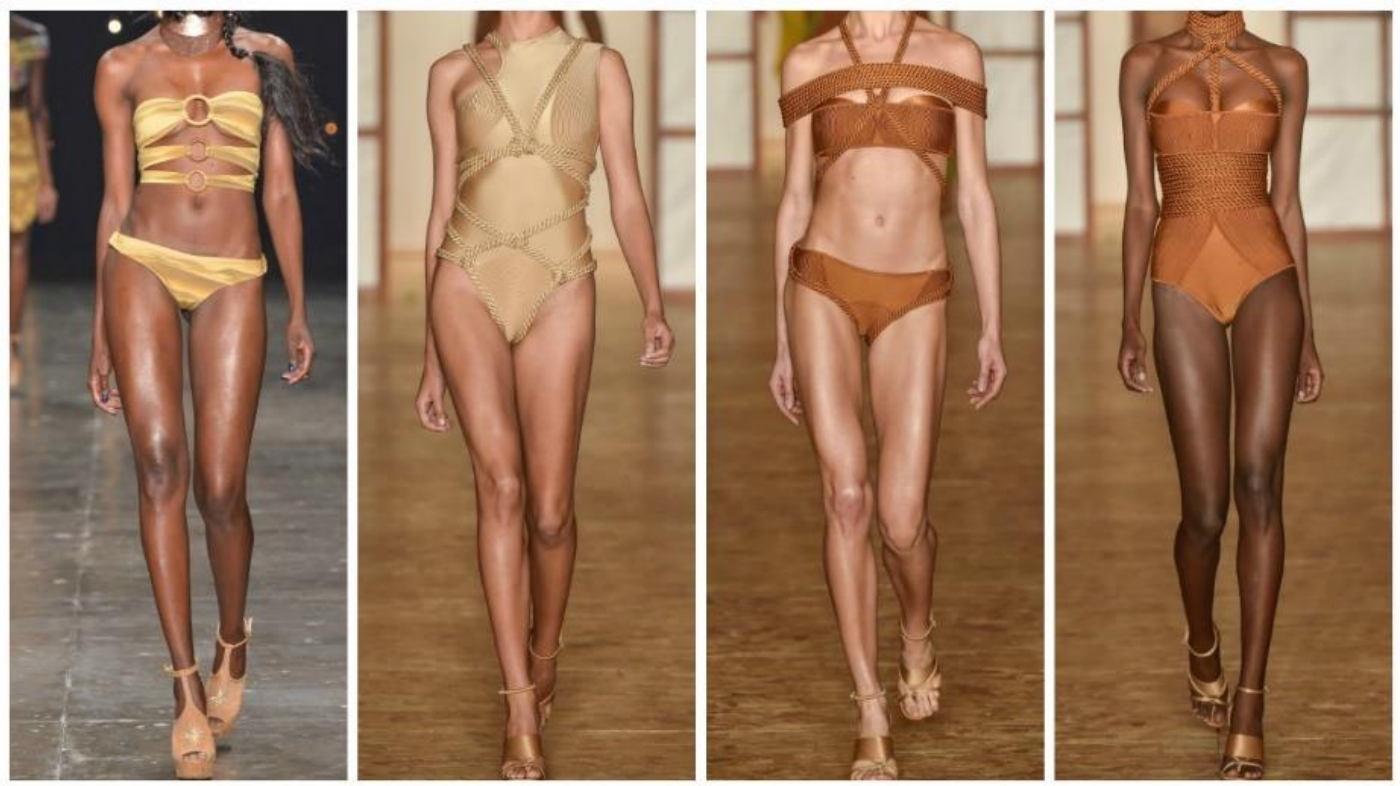

Figure № 6. earthy tones

Source: Adapted from FFW (2016) and RMR (2016)

The trends that have been identified in this topic are part of the first step in the process of elaborating a MWB product, that is, they are the materialization of the research done by the designers with the target audience and the environment that surrounds it. According to them, the products with handmade details, cut hang gliders, floral pattern, brown nuances and beach outfits in kimono style and long dress.

After identifying the fashionable Brazilian attributes listed by Sutter et al. (2014), an interconnection with the beach fashion segment was carried out, through the verification of the tendencies established for the summer of 2017 in the main fashion events of the country: SPFW and Rio Mode Rio. After this investigation, a correlation between trends and the Brazilian attributes were established, with the purpose of ascertaining where these attributes fit the beach fashion segment. And also, check if all elements of Brazilian are present in the collections of the next summer.

In this analysis, it was detected that the Brazilian attributes cited from Sutter et al. (2014) are really evident in fashion beach and some of them also can be classified as trend. A list was elaborated correlating these two traits, as can be visualized in Table 1. The first tendency studied is known as hang gliding, which is characterized by a higher cut in the groin region, it is directly related to the Brazilian attribute shapes and volumes. Once, the definition of this attribute is convenient with the modeling of the product, being: revealing, short or cut, making a mention of indigenous nudity.

Still in this same frame, the trend floral print corresponds to the Brazilian attribute called

\footnotetext{
"Visión de Futuro" Año 16, Volumen No 23 N², Julio - Diciembre 2019 - Pág. 157 - 171

URL de la Revista: http://visiondefuturo.fce.unam.edu.ar/index.php/visiondefuturo/index

URL del Documento: http://visiondefuturo.fce.unam.edu.ar/index.php/visiondefuturo/issue/view/16

ISSN 1668 - 8708 - Versión en Línea

E-mail: revistacientifica@fce.unam.edu.ar
} 
print. As described, it stands out for the presence of large, colorful flowers, tropical foliage or nature in general. And in the trends, the lush flowers appear prominently in the 2017 collection.

For the attribute application of craft techniques stood out the pieces with finishes and details made by hand (handmade). This was clearly recognized in beach trends, with the use of crochet, embroidery, hoops, fringes and ropes. The craftsmanship is very present in the Brazilian culture and its valorization is evident both in the trends of beach fashion and in the valorization of the general product of national fashion.

Table № 1. Beach fashion trends 2017 versus attributes of Brazilian fashion

\begin{tabular}{|c|c|c|c|}
\hline \multicolumn{2}{|c|}{ Requirements } & São Paulo Fashion Week & Rio Moda Rio \\
\hline \multirow[t]{2}{*}{ Lifestyle } & Brazilian & Kimono and long dress & Kimono and long dress \\
\hline & Tendencies & Kimono and long dress & Kimono and long dress \\
\hline \multirow[t]{2}{*}{$\begin{array}{l}\text { Representation } \\
\text { and national } \\
\text { symbols }\end{array}$} & $\begin{array}{l}\text { Brazilian fashion } \\
\text { attributes }\end{array}$ & $\begin{array}{l}\text { Representation of fauna (ounce), } \\
\text { macaw and toucan embroidered } \\
\text { in glitter and sequins }\end{array}$ & Not found \\
\hline & Tendencies & Not found & Not found \\
\hline \multirow[t]{2}{*}{ Colors } & $\begin{array}{c}\text { Brazilian fashion } \\
\text { attributes }\end{array}$ & Blue, green, yellow and red & $\begin{array}{l}\text { Blue, green, yellow and } \\
\text { orange }\end{array}$ \\
\hline & Tendencies & Earthy shades & Earthy shades \\
\hline \multirow[t]{2}{*}{$\begin{array}{l}\text { Natural raw } \\
\text { materials }\end{array}$} & $\begin{array}{c}\text { Brazilian fashion } \\
\text { attributes }\end{array}$ & Buriti fiber and seeds & Not found \\
\hline & Tendencies & Not found & Not found \\
\hline \multirow{2}{*}{$\begin{array}{l}\text { Craft } \\
\text { Applications } \\
\text { and Techniques }\end{array}$} & $\begin{array}{l}\text { Brazilian fashion } \\
\text { attributes }\end{array}$ & $\begin{array}{l}\text { Fringes, crochets, rings, } \\
\text { macrame and embroidery }\end{array}$ & Fringes \\
\hline & Tendencies & $\begin{array}{l}\text { Fringes, crochets, rings, } \\
\text { embroidery and ropes }\end{array}$ & Fringes \\
\hline \multirow[t]{2}{*}{ Fabrics } & $\begin{array}{c}\text { Brazilian fashion } \\
\text { attributes }\end{array}$ & Not found & Not found \\
\hline & Tendencies & Not found & Not found \\
\hline \multirow[t]{2}{*}{ Print } & $\begin{array}{l}\text { Brazilian fashion } \\
\text { attributes }\end{array}$ & $\begin{array}{l}\text { Big, colorful flowers (floral) and } \\
\text { fruits }\end{array}$ & $\begin{array}{l}\text { Large, colorful (floral) flowers } \\
\text { and tropical foliage }\end{array}$ \\
\hline & Tendencies & Big, colorful flowers (floral) & Big, colorful flowers (floral) \\
\hline \multirow[t]{2}{*}{$\begin{array}{l}\text { Shapes and } \\
\text { volumes }\end{array}$} & $\begin{array}{l}\text { Brazilian fashion } \\
\text { attributes }\end{array}$ & $\begin{array}{l}\text { Hang Glider Bikini, more } \\
\text { revealing cuts, open parts }\end{array}$ & $\begin{array}{l}\text { Hang Glider Bikini, more } \\
\text { revealing cuts, open parts }\end{array}$ \\
\hline & Tendencies & Hang Glider Bikini & Hang Glider Bikini \\
\hline
\end{tabular}

Source: Owrn Elaboration

Results from table 1 show trends in SPFW and RMR that can be classified as Brazilian attributes from Sutter et al. (2014) and a possible marketing hit. This findings can be classified as actual trends that were in both fashion events and are in hall of most relevant attributes of brasility, can be highlighted: Hang Glider Bikini at shape and volumes attribute; the floral fashion at print attribute; the fringes at the Craft Applications and Techniques; and the Kimono and long dress from brazilian cultural traditions that represent the lifestyle attribute.

Regarding the colors, there was a discrepancy about what is defined in the literature, Sutter et al. (2014), and trends. The events also revealed the presence of the colors defined in the literature: blue, green, yellow, orange and red, which are primary and secondary colors, however, the trends showed that the earth tones dominate this summer. The layout of these 
colors was inspired by the tanned skin of the Brazilian woman, so the definition by the shades of brown, gold and nude.

In the same way, the attribute of Brazilian lifestyle gained notoriety in the beach exit models. They were made with more sophisticated fabrics and more elegant forms, so that the customer may be ready for any opportunity to leave the beach, among them the Kimono and long dresses represent trends. This dichotomy experienced by the woman in being able to migrate from one environment to another follows the line of Delgado (2008) when she addresses the constant changes, and the new inspirations and tendencies, since the challenge of designing the same clothing for different environments, inspires the stylists in creating beach exits that allow technical and functional usability.

The attributes of Brazilianness natural raw materials and representation of Brazil and national symbols were found only in SPFW, however, this time they were not considered swimwear trends. This view is supported by Chan et al. (2017) who emphasize that responsiveness to customers and markets is an indispensable requirement. Among the attributes of Brazilian studies, cited by Sutter (2014), only the tissue was not found in any of the events studied, the use of ecological and sustainable tissues, apparently, were not used in the collections.

The beach fashion presented in the collection does not contain all the elements of Brazilian's due to market trends. The cultural metaphors are absorbed by the fashion industry, which adapts its products to contemporary women, adapting its portfolio according to the profile of women who are consumers of the moment.

It is probable that trends presented in fashion collections (figures 1, 2, 3 and 4) represents marketing work and shows that various characteristics that also are Brazilian attributes, such as: application of artisanal techniques, floral print and representation of Brazil and national symbols may be among the most commercialized pieces in the summer of 2017 . The similarity between the Beach fashion trends 2017 and the attributes of Brazilian fashion proposed by Sutter (2014), reaffirm that the cultural aspects create a market reality with consumption behaviors dictated by the avant-garde industry with marketing that proposes trends. This influence dictates the fashion of patterns that is consumed and serves the basis for an entire textile and clothing industry characterized by extremely volatile demands. Recognition of the industry-driven marketing opportunities is important and visionary. A business action that recognizes the needs of consumers who embrace ideas presented in fashion collections and is aligned with what says Ribeiro (2013), Rahman and Gong (2016), Schuch (2016) and Pereira et al. (2011).

\footnotetext{
"Visión de Futuro" Año 16, Volumen N²3 N², Julio - Diciembre 2019 - Pág. 157 - 171

URL de la Revista: http://visiondefuturo.fce.unam.edu.ar/index.php/visiondefuturo/index

URL del Documento: http://visiondefuturo.fce.unam.edu.ar/index.php/visiondefuturo/issue/view/16

ISSN 1668 - 8708 - Versión en Línea

E-mail: revistacientifica@fce.unam.edu.ar
} 


\section{CONCLUSION}

The purpose of this study was to verify if the Brazilian attributes are present in the fashion trends of the 2017 collections. To do this, was carried out by the main fashion vehicles to identify the product characteristics that emerged as a trend for this collection, they are: beach kimono model output, beach output as long dress, earthy nuances, craft use, and floral print panties with hang gliders cut. And that the attributes of Brazilianness defined by Sutter et al. (2014), are: lifestyle, representation of Brazil and national symbols, colors, natural raw materials, applications and techniques, fabrics, prints and shape and volume.

It is possible to conclude that the Brazilian attributes are part of the beach fashion segment, however, for the trends of 2017, conclude that the 4 requirements lifestyle, application of craft techniques, shape and volumen, and print attribute, are included at actual trends.

According to the results presented, it is possible to notice that marketing was able to meet in part the designs of the beachwear consumer. Through national symbols in the pieces marketed shows the presence of strong Brazilian characteristics: application of craft techniques, floral prints and representation of Brazil. In contrast, the study points out that the beach exits represented by the long dresses and the panties with hang gliders failed to meet the expectations of this consumer and probably will not have much fluidity in the commercialization.

This study identified the trends in relation to a collection, and such focus was achieved. The use of ecological and sustainable tissues was not perceived in this investigation. The importance of studies on the consumer market in which women assume a leading role is important, so it is suggested to carry out a survey about the 2018 and 2019 collection to verify the variability of the Brazilian results in relation to the dimensions identified in this study about MWB 2017.

It is probable that trends presented in 2017 fashion collections represents marketing work and shows that various characteristics that also are Brazilian attributes, such as: application of artisanal techniques, floral print and representation of Brazil and national symbols may be among the most commercialized pieces. In order to deepen the studies regarding female beachwear customer satisfaction, some actions are suggested that can add the ideas already spoken here. This study began to investigate the trends before the products were marketed, so to confirm the answers found in this study, it is suggested to conduct a survey in late summer of 2017 to check the quantity of products sold for each requirement. The latest recommendation is the expansion of the study to other international fashion events. 


\section{REFERENCES}

Please refer to articles in Spanish Bibliography.

\section{BIBLIOGRAPHCIAL ABSTRACT}

Please refer to articles Spanish Biographical abstract. 